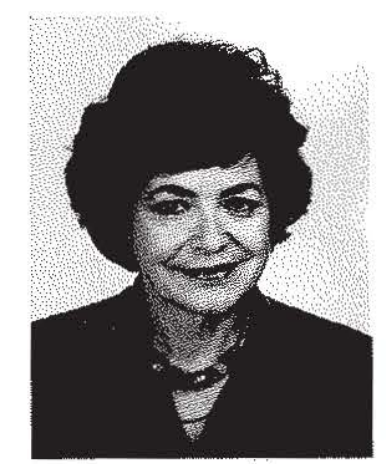

\title{
Kdo naj odloča o tem, česa naj se ljudje văijo?
}

Iz otroštva smo navajeni, da nas drugi poucujejo in brez nas odločajo o tem, česa se "moramo «aučiti. Tudi ko odrastemo, se učimo stvari, na katere naletimo po nakljucju, ali nam jih kdo vsili. Redko pa se zares poglobimo v to, česa se bomo učili in si napravimo načrt, po katerem bomo postopali. V pragozdu neznanja nam bolj po naključju kot po nekem izboru zasveti sedaj ta, nato drugi zarek znanja; razvese. limo se, če odkrijemo, da vemo pravo stvar. Brezbrižno pa se vedemo do tega, kaj drugi trpajo v naše glave.

Vse premalo govorimo o »onesnaženju duha". Onesnažena ni samo narava, onesnaženi smo lahko tudi ljudje $v$ načinu čustvovanja in razmišljanja. Zunanjo umazanijo pobereta voda in milo. Kaj pa notranjo? Napačna stališča, vtisi in podatki begajo naš duševni mir. Izgubljamo se v konfliktih s svetom okoli nas in s seboj. Vendar še vedno ne iščemo načrtne poti, kako bi si pomagali, da bi se iz vse te zmešnjave rešili. Ni nam vseeno, če nam v steklenico točijo vodo, mleko, razredčilo ali olje. Ni nam mar za našo zavest, kaj se z njo dogaja in s čim jo preplavljajo drugi, ki o vsebini izobraževanja odločajo namesto nas.

Ko pravimo, da drugi odločajo o tem, česa se bomo učili, da odločajo namesto nas o danes najbolj pomembnih stvareh, pomislimo zlasti na šolo, učne načrte, ki jih pripravljajo ponavadi od sveta in življenja odmaknjeni eksperti, pomislimo na ucitelja, ki nas poučuje in vztraja pri tem, da sprejmemo, kar nam viljuje.

Izobraževanje pa že zdavnaj ni več samo šola, ampak so to tudi vsi pomembnejši vplivi iz našega okolja. Ljudje razpolagajo z zelo učinkovitimi mediji. Kljub njihovi moči se brezbrižno odločajo za programe in upoštevajo morda le ceno filma in druge komercialne vidike, medtem ko jih »onesnaženje duha" nix ne skrbi. S televizijskih ekranov iz dneva v dan silijo v našo zavest nasilje, kriminal, poniževanje sočloveka in podobna navlaka. Ko kriminalistična služba objavi podatke o naglo naraščajoči agresivnosti in kriminalu, se javnost čudi, kot da to ni samo po sebi umevno, da je tako. Zgledov je dovolj za mlajše in starejše. Televizija pa je tudi dovolj učinkovit medij, da opravi svoje.

Tudi časopisi postajajo podobni branju grozljivk. Prevladujejo škandali, nasilje, tragične zgodbe o pobijanju $v$ vojnah, afere, nemorala in neuspehi. Ne da bi opazil, človek ob dnevnem prebiranju počasi zapada pesimizmu in se vedno bolj oddaljuje od svojega nekdanjega trdnega pozitivnega pogleda na svet ali pozitivne identifikacije. Vzgojni vplivi, ki so porinili človeka v negativno identifikacijo, so ga morda ohromili za vedno ali pa usaj za zelo dolgo časa. Kje bo našel dovolj opore in pomoci, da se bo spet dokopal do svetlejsih pogledov na svet in nase? Storjena škoda z »onesnaženjem duha« je lahko nepopravliviv.

Znanje postaja stvar preživetja in človekovega obstoja, zato je izbor znanja vedno pomembnejši. Ženske v Kanadi (v provincah Nove Fundlandije in Nove Škotske) tožijo državo, da jim v času, ko so bile zaposlene v industriji, ni omogočala izobraževanja in jih je tako danes privedla v nemogoč družbeni in osebni položaj. Ali bodo tudi pri nas delavci, ki so ostali brez izobrazbe, tožili državo, ker so premalo izobraženi in danes nimajo več od česa živeti?

Vse te in podobne razprave je učinkovito zaključila svetovna konferenca o permanentnem izobraževanju v Rimu, decembra 1994. Svetovni forum strokovnjakov je sprejel pomembne dokumente. V njih je najprej zapisano, da je za svoje izobraževanje in znanje najprej odgovoren vsak človek sam zase. Odgovornosti za to, česa se uči, ne more več prevaliti na druge. Podobno mora vedno bolj prevzemati tudi odgovornost za svoje zdravje, okolje, kjer biva, družino in drugo.

Človek odvisnež naj postane samostojno delujoči človek, vendar tesno vpet v svoje okolje.

Ana Krajnc 